\title{
Analisis Sebaran Jasa Ekosistem Penyediaan Pangan dan Air di Daerah Karst (Studi Kasus Kabupaten Buton Tengah)
}

\author{
La Baco $\mathrm{S}^{1, *}$, Kahirun $^{1}$, Zulkarnain $^{2}$, Albasri $^{2}$ \\ ${ }^{1}$ Jurusan IImu Lingkungan Fakultas Kehutanan dan IImu Lingkungan Universitas Halu Oleo Kendari, Indonesia. \\ ${ }^{2}$ Jurusan Kehutanan Fakultas Kehutanan dan IImu Lingkungan Universitas Halu Oleo Kendari, Indonesia. \\ Corresponding Author e-mail ${ }^{1}{ }^{*}:$ labaco.sudia@uho.ac.id \\ Diterima: 18 Februari 2020 - Disetujui: 30 April 2020 - Dipublikasi: 05 Mei 2020 \\ ๑) 2020 Jurusan Biologi FMIPA Universitas Halu Oleo Kendari, Indonesia.
}

\begin{abstract}
The karst area is the dominant ecosystem in the area of Central Buton District where around 80 percent is a stretch of karst. This objectives of the study was to analyze the ability of ecosystems to provide food and water and its distribution spatially in Central Buton District. This research was conducted through a study of ecoregion characteristics, including data on landscape, natural vegetation types and land cover. In addition, population data, water availability, food availability and administrative data in Central Buton District were collected. Data analysis includes the calculation of ecosystem service indexes, spatial distribution of ecosystem service indices and indicative status of the carrying capacity of food and water. The average index of environmental services for food supply in the Karst area of Central Buton District was 2.52 with a low category, while the index of environmental services for water supply was lower at 1.96 with also a low category. Food service ecosystem index with a low category dominates Central Buton District with an area of 50,286.63 hectares $(60.08 \%)$ and a medium category of $26,695.97$ hectares $(31.89 \%)$. Water supply ecosystem services index is very low to low with an area of $54,849.99$ hectares $(65.53 \%$ ) and $24,551.24$ hectares $(29.33 \%)$. The overall carrying capacity of food and water in Central Buton District is still a surplus. The area of food surplus in the region reached $66,977.53$ hectares $(80.02 \%)$ and the total food surplus was $30,453,510,374 \mathrm{kcal}$. The total area of water surplus in Central Buton District is 81,291 hectares $(97.12 \%)$ with a total surplus of $367,826,651$ m3/year.
\end{abstract}

Keywords: carrying capacity, ecoregion, ecosystem service index , karst area

\begin{abstract}
Abstrak
Kawasan karst merupakan ekosistem dominan di wilayah Kabupaten Buton Tengah dimana sekitar 80 persen merupakan hamparan karst. Penelitian ini bertujuan untuk menganalisis kemampuan ekosistem menyediakan pangan dan air serta distribusinya secara spasial di Kabupaten Buton Tengah. Penelitian ini dilakukan melalui kajian karakteristik ekoregion, mencakup data bentang lahan, tipe vegetasi alami dan tutupan lahan. Selain itu dilakukan pengumpulan data kependudukan, ketersediaan air, ketersediaan pangan dan data administrasi Kabupaten Buton Tengah. Analisis data meliputi perhitungan indeks jasa ekosistem, sebaran spasial indeks jasa ekosistem dan status indikatif daya dukung pangan dan air. Rerata indeks jasa lingkungan penyediaan pangan Kawasan Karst Kabupaten Buton Tengah adalah 2,52 dengan kategori rendah, sementara itu indeks jasa lingkungan penyediaan air lebih rendah yakni 1,96 dengan kategori juga rendah. Indeks jasa ekosistem penyediaan pangan dengan kategori rendah mendominasi Kabupaten Buton Tengah dengan luas 50.286,63 hektar (60.08 \%) dan kategori sedang seluas 26.695,97 hektar (31,89\%). Indeks jasa ekosistem penyediaan air kategori sangat rendah sampai rendah dengan luas masingmasing 54.849,99 hektar (65,53 \%) dan 24.551,24 hektar (29,33\%). Status daya dukung pangan dan air Kabupaten Buton Tengah secara keseluruhan masih surplus. Luas daerah surplus pangan di wilayah tersebut mencapai $66.977,53$ hektar $(80,02 \%)$ dan total surplus pangan sebanyak 30.453.510.374 kkal. Luas daerah surplus air Kabupaten Buton Tengah adalah 81.291 hektar $(97,12$ $\%$ ) dengan total surplus sebanyak $367.826 .651 \mathrm{~m}^{3} /$ tahun.
\end{abstract}

Kata Kunci: daya dukung, ekoregion, indeks jasa ekosistem, kawasan karst, sebaran spasial 


\section{PENDAHULUAN}

Kabupaten Buton Tengah terdiri dari 7 (tujuh) kecamatan yakni Kecamatan Lakudo, Mawasangka Timur, Mawasangka Tengah, Mawasangka, Gu, Talaga Raya dan Kecamatan Sangia Wambulu. Kabupaten Buton Tengah memiliki wilayah daratan seluas $\pm 958,31 \mathrm{~km}^{2}$. Kecamatan yang paling luas wilayahnya adalah Kecamatan Mawasangka dengan luas $269,55 \mathrm{~km}^{2} \quad(28,13 \%)$, Mawasangka Tengah dengan luas $152,22 \mathrm{~km}^{2}(15,88 \%)$, serta Kecamatan Mawasangka Timur dengan luas $126,23 \mathrm{~km}^{2}(13,17 \%)$ terhadap total luas wilayah Kabupaten Tengah.

Secara visual Kabupaten Buton Tengah merupakan hamparan kawasan karst dengan perkiraan lebih dari $80 \%$ luas wilayah Kabupaten Buton Tengah. Berdasarkan hal ini maka Kabupaten Buton Tengah dikenal dengan istilah "kawasan seribu gua" sehingga banyak sumber air yang berada di dalam gua. Hasil penelitian menunjukkan bahwa jumlah mata air di wilayah karst Kabupaten Buton Tengah adalah sebanyak 66 mata air (La Baco S., dkk, 2018).

Daya dukung lingkungan hidup wilayah karst ditentukan oleh besarnya jasa lingkungan yang dihasilkan oleh ekosistem alami wilayah tersebut. Daya dukung wilayah karst merupakan kemampuan ekosistem karst untuk menghasilkan jasa lingkungan sehingga besarnya jasa lingkungan yang dihasilkan sangat tergantung dari kondisi ekosistem alami kawasan karst tersebut. Mengingat ekosistem karst merupakan ekosistem yang unik, maka daya dukung ekosistem tersebut menjadi sangat penting untuk dikaji (Kremen, 2005; Kavouzi and Raeizi, 2015).

Secara garis besar maka jasa ekosistem wilayah karst Kabupaten Buton Tengah terdiri dari jasa penyediaan, jasa pengaturan, jasa sosial budaya dan jasa pendukung. Pada kasus perencanaan alokasi ruang maka jasa ekosistem yang dianalisis adalah jasa penyediaan, jasa pengaturan dan jasa pendukung, sedangkan jasa sosial budaya tidak dianalisis (Permen LH Nomor 17 Tahun 2009). Salah satu jasa ekosistem yang sangat penting adalah jasa penyediaan (providing services) yang mencakup jasa penyediaan pangan, jasa penyediaan air dan jasa penyediaan serat. Jasa ekosistem penyediaan pangan dan air merupakan jasa ekosistem yang vital bagi kehidupan di wilayah karst Kabupaten Buton Tengah (Bande, dkk., 2019).

Nilai jasa ekosistem penyediaan pangan dan penyediaan air wilayah karst Kabupaten Buton Tengah dipengaruhi oleh karakteristik ekoregion wilayah tersebut. Karakteristik ekoregion ini sangat tergantung dari karakteristik bentang lahan, tipe vegetasi alami dan tutupan lahan. Karakteristik bentang lahan Kabupaten Buton Tengah dicirikan oleh dominasi karst dengan tipe vegetasi alami hutan batu gamping monsun pamah pada bentang alam karst, sementara itu tutupan lahan didominasi savana/padang rumput dan semak belukar. Karakteristik ekoregion seperti ini merupakan ciri wilayah yang didominasi kawasan karst (Bande, La Baco, Zulkarnain dan Albasri. 2019).

Jasa ekosistem yang sangat penting untuk mendukung pembangunan di Kawasan Karst Kabupaten Buton Tengah adalah jasa ekosistem penyediaan pangan dan air. Jasa ekosistem penyediaan pangan di kawasan karst terkait erat dengan jumlah penduduk. Jasa ekosistem penyediaann pangan merupakan kemampuan ekosistem untuk menyediakan sumber kalori yang dibutuhkan oleh manusia maupun hewan di wilayah tersebut. Jasa ekosistem penyediaan air berkaitan dengan kemampuan ekosistem mensuplai berbagai kebutuhan air seperti kebutuhan air domestik industri dan kebutuhan air irigasi (pertanian). Informasi tentang sebaran spasial jasa ekosistem 
penyediaan pangan dan air merupakan faktor kunci untuk pengalokasian kebutuhan ruang wilayah di Kabupaten Buton Tengah.

Kabupaten Buton Tengah sebagai salah satu daerah otonom akan mengalami perkembangan pesat sehingga informasi tentang daya dukung wilayah sangat diperlukan. Informasi tentang daya dukung wilayah yang sangat diperlukan adalah daya dukung pangan dan daya dukung air. Penyebaran spasial layanan jasa ekosistem penyediaan pangan dan penyediaan air selanjutnya digunakan sebagai pertimbangan untuk menentukan alokasi pola ruang wilayah tersebut. Berdasarkan uraian-uraian tersebut di atas maka perlu dilakukan penelitian tentang analisis jasa ekosistem penyediaan pangan dan air wilayah karst di Kabupaten Buton Tengah.

Penelitian ini bertujuan untuk menganalisis: (1) karakteristik ekoregion wilayah karst Kabupaten Buton Tengah, (2) daya dukung pangan dan daya dukung air wilayah karst di Kabupaten Buton Tengah, dam (3) sebaran spasial indeks jasa ekosistem penyediaan pangan dan air kawasan karst Kabupaten Buton Tengah.

\section{METODE PENELITIAN}

Penelitian ini dilaksanakan di Kawasan Karst Kabupaten Buton Tengah Provinsi Sulawesi Tenggara. Secara administrasi penelitian dilaksanakan di seluruh wilayah administrasi Kabupaten Buton Tengah. Penelitian ini dilaksanakan selama 3 (tiga) bulan yakni Bulan Juni 2019 sampai Bulan Agustus 2019.

Layanan jasa ekosistem penyediaan pangan dan penyediaan air kawasan karst Kabupaten Buton Tengah menggunakan unit analisis administrasi kecamatan. Pelaksanaan analisis layanan jasa ekosistem dilakukan melalui 4 (empat) tahap, yakni: (1) pengumpulan data spasial yang meliputi karakteristik bentang lahan, tipe vegetasi alaami, tipe penggunaan lahan, administrasi dan data jaringan jalan) serta data non spasial yang terdiri dari data kependudukan, ketersediaan air, produksi pangan dan neraca bahan pangan; (2) input data: pada tahapan ini dilakukan klasifikasi karateristik ekoregion (karakteristik bentang lahan, tipe vegetasi alami dan tipe penggunaan lahan), sekaligus menetapkan bobot dan skor yang digunakan pada setiap karakteristik ekoregion; (3) proses: penentuan layanan jasa ekosistem, penentuan indeks layanan jasa ekosistem dan pembuatan peta layanan jasa ekosistem; dan (4) output: penentuan dan pembuatan peta status jasa ekosistem penyediaan pangan dan penyediaan air.

Daya dukung ekosistem penyediaan pangan dan air Kawasan Karst Kabupaten Buton Tengah dilakukan dengan menggunakan acuan Peraturan Menteri Lingkungan Hidup Nomor 17 Tahun 2009. Nilai indeks jasa ekosistem penyediaan pangan dan penyediaan air secara khusus mengacu pada Peraturan Direktorat Jenderal Planologi Kehutanan dan Tata Lingkungan Kementerian Lingkungan Hidup dan Kehutanan Tahun 2017.

Penentuan indeks jasa ekosistem dilakukan melalui penjumlahan hasil kali antara bobot dan skor bentang lahan, vegetasi alami dan penggunaan lahan. Kebutuhan air yang diperhitungkan adalah kebutuhan air penduduk dan kebutuhan air lahan (Permen LH Nomor 17 Tahun 2009). Perhitungan ketersediaan air permukaan menggunakan data dari Balai Wilayah Sungai Sulawesi IV (2017), sedangkan ketersediaan air tanah menggunakan data Dinas Energi dan Sumberdaya Mineral Provinsi Sulawesi Tenggara (2018). Ketersediaan pangan ditentukan berdasarkan data neraca bahan pangan Kabupaten Buton Tengah (Badan Ketahanan Pangan Kabupaten Buton Tengah, 2019), sedangkan kebutuhan pangan penduduk dihitung berdasarkan 
standar kebutuhan kalori setiap orang agar dapat hidup layak.

\section{HASIL DAN PEMBAHASAN \\ Karakteristik Ekoregion Kawasan Karst Kabupaten Buton Tengah}

Berdasarkan tipe bentang lahannya maka Kawasan Karst Kabupaten Buton Tengah di dominasi oleh tipe bentang lahan dataran solusional karst bermaterial batuan sedimen karbonat dengan luas $37.347,81$ hektar atau 44,62 \% dari luas wilayah Kabupaten Buton Tengah. Tipe bentang lahan dominan lainnya adalah perbukitan solusional karst bermaterial batuan sedimen karbonat dengan luas 31.696,53 hektar atau $37,87 \%$ dari total luas Kabupaten Buton Tengah. Salah satu syarat terbentukanya tipe bentang lahan ini adalah Vegetasi penutup yang lebat, Vegetasi yang rapat akan menghasilkan humus, yang menyebabkan air memiliki $\mathrm{pH}$ rendah atau asam. Pada kondisi asam, air akan mudah melarutkan karbonat $\left(\mathrm{CaCO}_{3}\right)$. Kombinasi ini akan mempercepat pembentukan batuan. Karakteristik bentang lahan Kawasan Karst Kabupaten Buton Tengah disajikan pada Tabel 1.

Tabel 1. Karakteristik Bentang Lahan Kawasan Karst Kabupaten Buton Tengah.

\begin{tabular}{clrc}
\hline \multirow{2}{*}{ No } & \multicolumn{2}{c}{ Bentang Lahan } & \multicolumn{2}{c}{ Luas } \\
\cline { 3 - 4 } & & $3.144,59$ & 3,76 \\
\hline 1 & Dataran fluvial bermaterial aluvium & $6.259,89$ & 7,48 \\
2 & Dataran fluviomarin bermaterial aluvium & $37.347,81$ & 44,62 \\
3 & Dataran solusional karst bermaterial batuan sedimen karbonat & 610,45 & 0,73 \\
4 & Lembah fluvial bermaterial aluvium & $31.696,53$ & 37,87 \\
5 & Perbukitan solusional karst bermaterial batuan sedimen karbonat & 958,93 & 1,15 \\
6 & Perbukitan struktural lipatan bermaterial batuan sedimen non karbonat & $3.684,21$ & 4,40 \\
7 & Perbukitan vulkanik bermaterial batuan beku luar & $83.702,41$ & 100,01 \\
\hline & Total & &
\end{tabular}

Sumber: Analisis SIG (2019)

Tabel 2. Karakteristik Vegetasi Alami Kawasan Karst Kabupaten Buton Tengah

\begin{tabular}{llrc}
\hline \multirow{2}{*}{ No } & \multicolumn{1}{c}{ Tipe Vegetasi } & \multicolumn{2}{c}{ Luas } \\
\cline { 3 - 4 } & & \multicolumn{1}{c}{ ha } & $\%$ \\
\hline 1 & Vegetasi hutan batuan ultrabasa pamah & $7.787,74$ & 9,30 \\
2 & Vegetasi hutan batugamping monsun pamah pada bentang alam karst & $44.485,77$ & 53,15 \\
3 & Vegetasi hutan batugamping pamah monsun & $24.558,57$ & 29,34 \\
4 & Vegetasi hutan rawa air tawar pada bentang alam karst & 610,45 & 0,73 \\
5 & Vegetasi mangrove & $6.259,89$ & 7,48 \\
\hline \multicolumn{2}{c}{ Total } & $83.702,41$ & 100,00 \\
\hline
\end{tabular}

Tipe vegetasi alami kawasaan karst Kabupaten Buton Tengah berdasarkan data dari Direktorat Planologi Kehutanan dan Tata Lingkungan KLHK 2017 menununjukan bahwa tipe vegetasi alami terdiri dari lima tipe vegetasi alami (Tabel 2). Dapat diketahui bahwa kawasan karst Kabupaten Buton Tengah didominasi oleh tipe vegetasi hutan batu gamping monsun pamah pada bentang alam karst dengan luas 44.485,77 hektar atau 53,15\% dari total luas Kabupaten Buton Tengah. Selain itu vegetasi alami yang dominan berikutnya adalah vegetasi hutan batu gamping pamah onsun dengan luas 24.558,57 hektar atau 29,34\% dari total luas Kabupaten Buton Tengah. Selain itu tipe vegetasi hutan batuan ultra basa pamah juga cukup dominan dengan luas $7.787,74$ 
hektar atau 9,30 \% dari total luas Kabupaten Buton Tengah. Komposisi vegetasi alami ini akan menentukan indeks jasa ekosistem di Kabupaten Buton Tengah.

Berdasarkan peta Penutupan Lahan Kabupaten Buton Tengah tahun 2017, yang bersumber dari BPKH Wilayah XXII, diketahui bahwa kawasan karst Kabupaten Buton Tengah terdiri atas 16 tipe penutupan lahan. Tipe penutupan lahan selengkapnya di Kabupaten Buton Tengah disajikan pada Tabel 3.

Tabel 3. Tipe Penutupan Lahan Kabupaten Buton Tengah

\begin{tabular}{clrc}
\hline \multirow{2}{*}{ No } & & \multicolumn{2}{c}{ Luas } \\
\cline { 2 - 4 } 1 & Badan Air & ha & $\%$ \\
2 & Belukar & 51,85 & 0,06 \\
3 & Belukar Rawa & $18.895,98$ & 22,58 \\
4 & Hutan Lahan Kering Sekunder & 266,66 & 0,32 \\
5 & Hutan Mangrove Primer & $1.572,73$ & 1,88 \\
6 & Hutan Mangrove Sekunder & 510,81 & 0,61 \\
7 & Hutan Rawa Sekunder & $1.840,54$ & 2,20 \\
8 & Pemukiman & $1.994,37$ & 2,38 \\
9 & Pertambangan & $1.520,82$ & 1,82 \\
10 & Pertanian Lahan Kering & 406,96 & 0,49 \\
11 & Pertanian Lahan Kering Campur & $2.293,20$ & 2,74 \\
12 & Savanna/ Padang rumput & $2.233,57$ & 2,67 \\
13 & Sawah & $48.645,32$ & 58,12 \\
14 & Tambak & 84,81 & 0,10 \\
15 & Tanah Terbuka & 4,85 & 0,01 \\
\hline & & $3.379,94$ & 4,04 \\
\hline
\end{tabular}

Sumber: Analisis SIG (2019)

Tabel 3 di atas menunjukan bahwa $58,12 \%$ dari total keseluruhan daratan Kabupaten Buton Tengah didominasi oleh savana/padang rumput dengan luas 48.645,32 hektar. Selain itu tutupan lahan yang dominan berikutnya adalah belukar dengan luas 18.895,98 hektar atau sekitar $22,58 \%$ dari total luas Kabupaten Buton Tengah. Lebih lanjut dijelaskan bahwa tanah terbuka merupakan tutupan lahan dominan ketiga dengan luas 3.379,94 hektar atau sekitar 4,04\% dari total luas Kabupaten Buton Tengah, sementara itu penggunaan lahan pertanian lahan kering campur juga cukup dominan dengan luas $2.233,57$ hektar atau sekitar 2,67 \% dari total luas wilayah Kabupaten Buton Tengah.

\section{Indeks Jasa Ekosistem Penyediaan Pangan dan Air Kawasan}

Jasa ekosistem penyediaan pangan dan air kawasan karst Kabupaten Buton Tengah ditunjukkan oleh rata-rata nilai indeks masing-masing kategori. Nilai indeks jasa lingkungan penyediaan pangan dan air wilayah tersebut yang dirinci menurut administrasi kecamatan disajikan pada Tabel 4 dan sebaran spasialnya disajikan pada Gambar 1.

Tabel 4. Nilai Indeks Jasa Lingkungan Penyediaan Pangan dan Air Kawasan Karst Kabupaten Buton Tengah menurut Administrasi Kecamatan. 


\begin{tabular}{clcc}
\hline No. & Kecamatan & $\begin{array}{c}\text { IJL } \\
\text { Pangan }\end{array}$ & $\begin{array}{c}\text { IJL } \\
\text { Air }\end{array}$ \\
\hline 1. & Gu & 2,52 & 1,84 \\
2. & Lakudo & 2,48 & 1,77 \\
3. & Mawasangka & 2,81 & 2,12 \\
4. & Mawasangka Timur & 2,39 & 1,85 \\
5. & Mawasangka Tengah & 2,24 & 1,69 \\
6. Sangia Wambulu & 2,30 & 2,27 \\
7. & Talaga Raya & 2,91 & 2,16 \\
\hline \multicolumn{2}{c}{ Rerata } & $\mathbf{2 , 5 2}$ & $\mathbf{1 , 9 6}$ \\
\hline
\end{tabular}

Sumber: Hasil Analisis (2019)

Keterangan: $1,00-1,79=$ sangat rendah; $1,40-$ $2,59=$ rendah; $2,60-3,39=$ sedang; $3,40-4,19=$ tinggi dan 4,20-4,99= sangat tinggi

Tabel 4 menunjukkan bahwa rerata indeks jasa lingkungan penyediaan pangan Kawasan Karst Kabupaten Buton Tengah adalah 2,52. Nilai tersebut merupakan nilai kumulatif indeks jasa lingkungan masingmasing kecamatan dengan nilai rerata berkisar antara 2,24 (nilai terendah) yang terdapat di Kecamatan Mawasangka Tengah sampai dengan 2,91 (nilai tertinggi) yang terdapat di Kecamatan Talaga Raya.
Nilai rerata indeks jasa lingkungan kawasan karst di wilayah tersebut tergolong rendah, kecuali indeks jasa ekosistem penyediaan pangan di Kecamatan Mawasangka dan Kecamatan Talaga Raya termasuk katogori sedang.

Tabel 4 juga menjelaskan bahwa rerata nilai indeks jasa lingkungan penyediaan air Kawasan Karst Kabupaten Buton Tengah adalah 1,96, tergolong rendah. Nilai tersebut lebih rendah jika dibandingkan dengan nilai indeks jasa lingkungan penyediaan pangan di wilayah tersebut. Indeks jasa lingkungan penyediaan air tertinggi adalah Kecamatan Sangia Wambulu dengan nilai 2,27, sementara indeks jasa ekosistem penyediaan air terendah terdapat di Kecamatan Mawasangka Tengah dengan nilai 1,69. Nilai indeks jasa ekosiste penyediaan air kawasaan karst Kabupaten Buton Tengah tergolong kategori rendah.

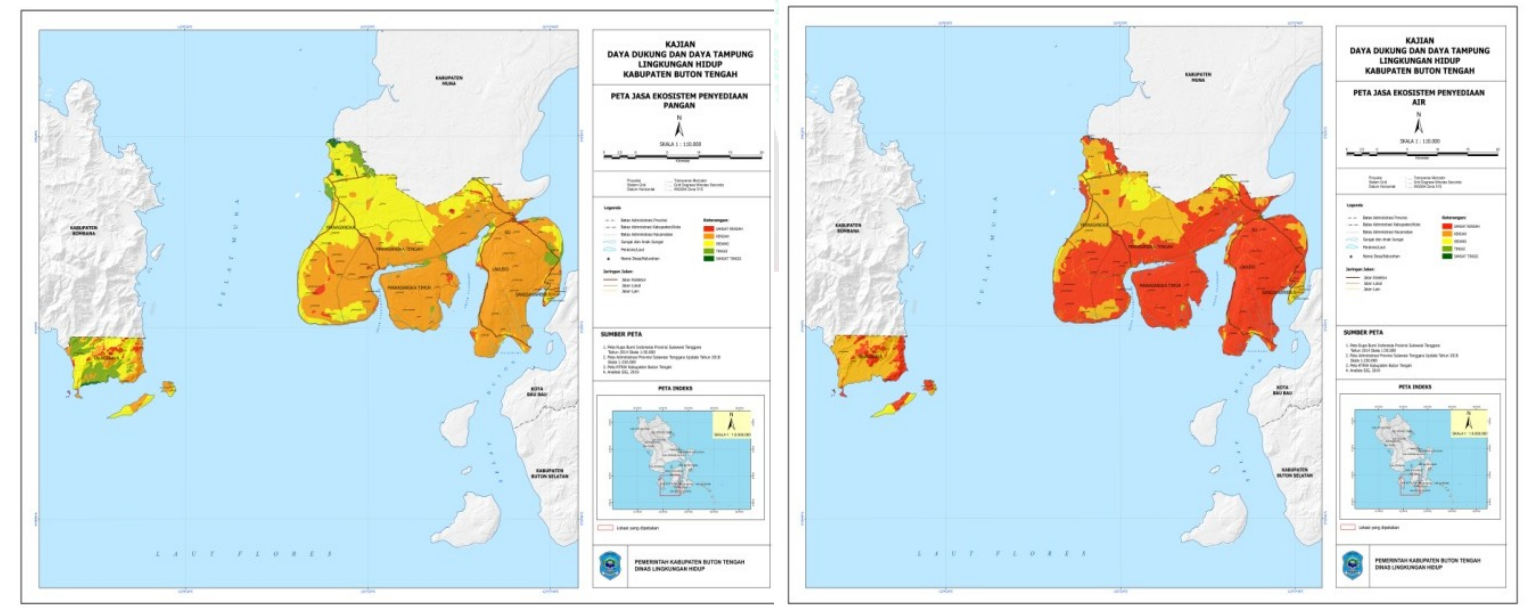

Gambar 1. Sebaran Spasial Indeks Jasa Lingkungan Penyediaan Pangan (kiri) dan Penyediaan Air (kanan) Kawasan Karst Kabupaten Buton Tengah

Hasil analisis spasial peta sebaran indeks jasa lingkungan penyediaan pangan dan penyediaan air Kawasan Karst Kabupaten Buton Tengah menunjukkan bahwa sebagian besar luas wilayah tersebut mempunyai indeks jasa lingkungan sedang baik indeks penyediaan pangan maupun indeks penyediaan air. Sebaran spasial indeks jasa ekosistem penyediaan pangan dan penyediaan air Kawasan Karst Kabupaten Buton Tengah disajikan pada Tabel 5. 
Tabel 5. Luas Sebaran Spasial Indeks Jasa Lingkungan Penyediaan Pangan dan Penyediaan Air Kawasan Karst Kabupaten Buton Tengah

\begin{tabular}{lrrrrr}
\hline \multirow{2}{*}{ Jasa Ekosistem } & \multicolumn{5}{c}{ Luas Masing-masing Kategori } \\
\cline { 2 - 6 } & Sangat Rendah & \multicolumn{1}{c}{ Rendah } & Sedang & Tinggi & Sangat Tinggi \\
\hline Penyediaan & $2.076,11$ & $50.286,63$ & $26.695,97$ & $4.304,79$ & 338,91 \\
Pangan (ha, \%) & 2,48 & 60,08 & 31,89 & 5,14 & 0,40 \\
\hline Penyediaan Air & $54.849,99$ & $24.551,24$ & $4.249,33$ & 51,85 & - \\
(ha, \%) & 65,53 & 29,33 & 5,08 & 0,06 & - \\
\hline
\end{tabular}

Sumber: Hasil Analisis Gambar 1

Tabel 5 menunjukkan bahwaa sebaran spasial jasa ekosistem penyediaan pangan kategori rendah mendominasi Kawasan Karst Kabupaten Buton Tengah dengan luas 50.286,63 hektar atau sekitar $60,08 \%$ dari total luas Kabupaten Buton Tengah. Selanjutnya sebaran spasial indeks jasa ekosistem sedang merupakan angka tertinggi berikutnya yakni seluas 26.695,97 hektar atau sekitar 31,89\%, sementara itu indeks jasa ekosistem penyediaan pangan dengan kategori tinggi mencapai luas 4.304,79 hektar atau sekitar $5,14 \%$. Jasa ekosistem penyediaan pangan dengan kategori rendah sampai sedang mendominasi sebagian besar Kawasan Karst Kabupaten Buton Tengah. Hal ini disebabkan oleh pengaruh karakteristik ekoregion yang meliputi karakteristik bentang lahan, tipe vegetasi alami dan tipe tutupan lahan (Kremen, 2005; de Groot, et al., 2912; Pandeya, et al., 2016; Braat and de Groot, 2012). Kabupaten Buton Tengah didominasi oleh tipe bentang lahan dataran solusional karst bermaterial batuan sedimen karbonat dengan luas $37.347,81$ hektar atau $44,62 \%$ dari luas wilayah Kabupaten Buton Tengah. Tipe bentang lahan dominan lainnya adalah perbukitan solusional karst bermaterial batuan sedimen karbonat dengan luas 31.696,53 hektar atau 37,87\% dari total luas Kabupaten Buton Tengah. Bentang lahan yang didominasi karst mempunyai kemampuan untuk menyediakan pangan yang relatif rendah (Vigna, et al., 2017; Hall and Day, 2011; Nasimmi and Mohammadi, 2015). Selain itu vegetasi alami Kabupaten Buton Tengah yang didominasi hutan batu gamping monsun pamah pada bentang lahan karst 44.485,77 hektar atau sekitar 53,15\% dan tipe penutupan lahan dominan berupa savana padang rumput dengan luas 48.645,32 hektar atau 58,12 \% dari total luas Kabupaten Buton Tengah. Kondisi seperti ini sangat besar peranannya untuk menghasilkan indeks jasa ekosistem penyediaan pangan yang tinggi. Oleh karena itu maka daya dukung Kawasan Karst Kabupaten Buton Tengah akan tetap terjaga jika vegetasi hutan tetap dipertahankan (Senoaji, 2019; Kavouzi and Raeizi. 2015; Smiley, 2018).

Tabel 5 juga menunjukkan bahwa indeks jasa ekosistem penyediaan air Kawasan Karst Kabupaten Buton Tengah yang dominan adalah kategori rendah sampai sedang. Luas wilayah Kabupaten Buton Tengah yang memunyai indeks jasa lingkungan kategori rendah adalah $54.849,99$ hektar atau $65,53 \%$ dari luas wilayah Kabupaten Buton Tengah. Luas wilayah dengan indeks jasa ekosistem sedang adalah 24.551,24 hektar atau sekitar 29,33 \% dari total luas Kabupaten Buton Tengah. Hal ini dipengaruhi juga oleh karakteristik ekoregion yakni bentang lahan, tipe vegetasi alami dan penggunaan lahan. Nilai skor masing-masing parameter indeks jasa lingkungan penyediaan air berdasarkan karakteristik ekoregion Kabupaten Buton Tengah umumnya berkisar antara 2 - 3 sehingga akumulasi nilai seluruh variabel juga berada pada kategori rendah sampai sedang (La Baco, Zulkarnain, dan Albasri, 2019). Hal ini sejalan dengan Kremen (2005); de Groot, et al. (2012); Pandeya, et al. (2016) dan Braat 
and de Groot (2012) bahwa jasa ekosistem penyediaan air sangat ditentukan oleh karakteristik ekoregion yang mencakup karakteristik bentang lahan, tipe vegetasi alami dan tutupan lahan (Kavousi and Raeisi, 2015; Shokri et al., 2014).

\section{Status Daya Dukung Ekosistem Penyediakan Pangan dan Air}

Status daya dukung ekosistem Kawasan Karst Kabupaten Buton Tengah dalam menyediakan pangan dan air merupakan perbandingan antara ketersediaan pangan dan air dengan kebutuhan pangan dan air di wilayah tersebut. Ketersediaan pangan dan air merupakan jasa ekosistem yang dipengaruhi oleh karakteristik ekoregion.

Perhitungan status daya dukung ekosistem dilakukan melalui pendekatan kuantitatif dengan menghitung selisih antara ketersediaan dan kebutuhan untuk masingmasing jasa ekosistem. Hasil analisis daya dukung indikatif status pangan dan air Kawasan Karst Kabupaten Buton Tengah disajikan pada Tabel 6.

Tabel 6. Daya Dukung Indikatif Status Pangan dan Air Kawasan Karst Kabupaten Buton Tengah

\begin{tabular}{|c|c|c|c|c|}
\hline Variabel & Ketersediaan & Kebutuhan & Selisih & Status \\
\hline Pangan (x 1000 kkal) & 102.010 .939 .124 & 71.557 .428 .750 & 30.453 .510 .374 & Surplus \\
\hline Air (x $1000 \mathrm{~m}^{3} /$ tahun) & 406.719 .792 & 38.893 .141 & 367.826 .651 & Surplus \\
\hline
\end{tabular}

Tabel 6 menunjukkan bahwa kemampuan ekosistem menyediakan pangan di Kabupaten Buton Tengah yang berkisar antara rendah sampai sedang ditunjukkan oleh angka ketersediaan pangan yang cukup memadai. Ketersediaan pangan di wilayah tersebut adalah 102.010.939.124 kkal, sementara itu jumlah kebutuhan pangan di wilayah tersebut adalah 71.557.428.750 kkal. Berdasarkan fakta tersebut maka Kabupaten Buton Tengah memiliki surplus pangan sebesar 30.453.510.374 kkal. Berdasarkan status tersebut maka dapat dikatakan bahwa jasa ekosistem penyediaan pangan Kabupaten Buton Tengah masih mampu mendukung kebutuhan pangan di wilayah tersebut.

Tabel 6 juga menunjukkan bahwa kemampuan ekosistem menyediakan air yang ditunjukkan oleh total ketersediaan air di Kabupaten Buton Tengah adalah 406.719.792 $\mathrm{m}^{3} /$ tahun. Angka tersebut merupakan ketersediaan air permukaan (Balai Wilayah Sungai Sulawesi IV, 2017) dan ketersediaan air tanah (Dinas Energi dan Sumberdaya Mineral, 2018).
Kebutuhan air yang meliputi kebutuhan air penduduk dan kebutuhan air lahan (Permen LH Nomor 17 Tahun 2009) Kabupaten Buton Tengah adalah $38.893 .141 \mathrm{~m}^{3} /$ tahun. Berdasarkan ketersediaan dan kebutuhan air tersebut maka status air di Kabupaten Buton Tengah secara keseluruhan masih suplus dengan nilai $367.826 .651 \mathrm{~m}^{3} /$ tahun. Tingginya nilai surplus air tahunan di Kabupaten Buton Tengah mengindikasikan bahwa pengembangan ekonomi wilayah yang membutuhkan air masih sangat mungkin mengingat kecenderungan peningkatan kebutuhan air sektor pertanian, industri dan domestik (Kavousi and Raeisi, 2015; Shokri et al ., 2014; Zhu, et al., 2009; Biswas and Tortajada, 2019; La Baco, dkk, 2018; Luker and Harris, 2018; Smiley, 2018; Calatrava and Granados, 2018).

Status daya dukung pangan dan air Kabupaten Buton Tengah secara keseluruhan masih surplus. Analisis spasial status daya dukung pangan dan air Kabupaten Buton Tengah menunjukkan bahwa terdapat bagian wilayah yang berstatus defisit. Ini berarti bahwa ketersediaan pangan dan air di bagian 
wilayah tersebut lebih rendah dibandingkan dengan kebutuhan pangan dan air. Hasil analisis spasial daerah surplus dan defisit pangan dan air Kabupaten Buton Tengah disajikan pada Tabel 7 dan Gambar 2.

Tabel 7. Luas Daerah berdasarkan Status Pangan dan Air Kabupaten Buton Tengah

\begin{tabular}{lcccc}
\hline Variabel & \multicolumn{2}{c}{ Daerah Suplus } & \multicolumn{2}{c}{ Defisit } \\
\cline { 2 - 5 } & Luas (ha) & Proporsi (\%) & Luas (ha) & Proporsi (\%) \\
\hline Pangan & $66.977,53$ & 80,02 & $16.724,88$ & 19,98 \\
Air & 81.291 & 97,12 & 2.411 & 2,88 \\
\hline
\end{tabular}

Sumber: Hasil Analisis (2019)

Tabel 7 menunjukkan bahwa luas daerah surplus pangan adalah 66.977,53 hektar atau 80,02 \%, sementara itu luas daerah defisit pangan mencapai $16.724,88$ hektar atau sekitar $19,98 \%$ dari luas Kabupaten Buton Tengah. Lebih lanjut dijelaskan bahwa luas daerah surplus air di Kabupaten Buton Tengah adalah 81.291 hektar atau $97,12 \%$ dan luas daerah defisit air di wilayah tersebut mencapai 2.411 hektar atau sekitar 2,88 \% dari total luas Kabupaten Buton Tengah. Berdasarkan angka-angka tersebut maka jelas bahwa kondisi ekosistem Kabupaten Buton Tengah masih relatif baik. Kondisi daya dukung ekosistem tersebut akan dipengaruhi oleh intervensi manusia (Hein, et al., 2006).
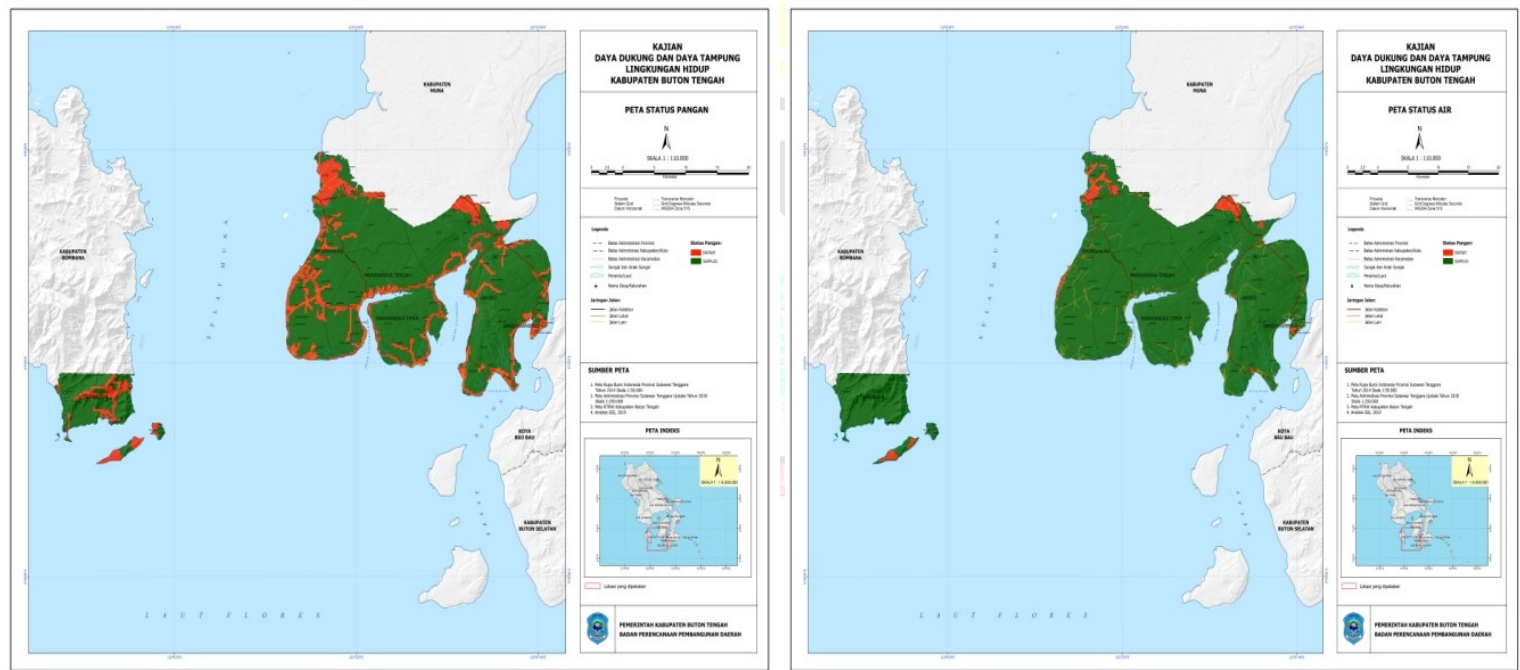

Gambar 2. Sebaran Spasial Daerah Surplus dan Defisit Pangan (kiri) dan Air (kanan) Kabupaten Buton Tengah

Gambar 2 menunjukkan bahwa pola sebaran daerah surplus dan defisit pangan dan air hampir sama. Daerahdaerah yang surplus air juga akan cenderung surplus pangan dan sebaliknya daerah-daerah yang defisit air juga akan cenderung defisit pangan. Hal ini terkait dengan kemampuan ekosistem menyediakan air yang erat kaitannya dengan kemampuan ekosistem menyediakan pangan. Daerah-daerah yang mempunyai indeks jasa ekosistem tinggi akan cenderung mempunyai kemampuan menyediakan air dan pangan yang tinggi, demikian pula sebaliknya. Kemampuan ekosistem menyediakan pangan dan air sebagaimana diperlihatkan pada Gambar 2 di atas dipengaruhi oleh karakteristik ekoregion yakni bentang lahan, tipe vegetasi alami dan tutupan lahan. Status daya dukung pangan dan air sangat penting untuk pengembangan berbagai sektor seperti sektor pertanian, perkebunan, peternakan, perikanan, kehutanan dan sektor 
pariwisata (Qiuyun, et al., 2011; Cisneros, et al., 2016; Nam, et al., 2010). Status daya dukung pangan dan air akan cenderung menurun seiring kecenderungan peningkatan populasi penduduk (Brook, 2004; Hanjra and Qureshi, 2010).

\section{KESIMPULAN}

Rerata indeks jasa lingkungan penyediaan pangan Kawasan Karst Kabupaten Buton Tengah adalah 2,52 dengan kategori rendah, sementara itu indeks jasa lingkungan penyediaan air lebih rendah yakni 1,96 dengan kategori juga rendah. Indeks jasa ekosistem penyediaan pangan dengan kategori rendah mendominasi Kabupaten Buton Tengah dengan luas 50.286,63 hektar $(60.08 \%)$ dan kategori sedang seluas $26.695,97$ hektar $(31,89 \%)$. Indeks jasa ekosistem penyediaan air kategori sangat rendah sampai rendah dengan luas masing-masing $54.849,99$ hektar $(65,53$ $\%)$ dan 24.551,24 hektar $(29,33 \%)$. Status daya dukung pangan dan air Kabupaten Buton Tengah secara keseluruhan masih surplus. Luas daerah surplus pangan di wilayah tersebut mencapai $66.977,53$ hektar $(80,02 \%)$ dan total surplus pangan sebanyak 30.453.510.374 kkal. Luas daerah surplus air Kabupaten Buton Tengah adalah 81.291 hektar $(97,12 \%)$ dengan total surplus sebanyak $367.826 .651 \mathrm{~m}^{3} /$ tahun.

\section{DAFTAR PUSTAKA}

Badan Ketahanan Pangan Kabupaten Buton Tengah. 2018. Neraca Bahan Pangan Kabupaten Buton Tengah. Labungkari, Buton Tengah.

Badan Pusat Statistik Kabupaten Buton Tengah. 2018. Kabupaten Buton Tengah Dalam Angka Tahun 2018. Labungkari, Buton Tengah.
Dinas Sumber Daya Air dan Bina Marga Provinsi Sulawesi Tenggara. 2018. Data Sumber Daya Air Wilayah Sungai Muna. Kendari, Sulawesi Tenggara.

Bande, S., La Baco, Zulkarnain dan Albasri. 2019. Analisis Daya Dukung dan Daya Tampung Lingkungan Hidup Kabupaten Buton Tengah. Kerjasama Badan Perencanaan Pembangunan Daerah Kabupaten Buton Tengah dengan Lembaga Penelitian dan Pengabdian Kepada Masyarakat Universitas Halu Oleo. Labungkari, Buton Tengah.

Biswas, A.K. and C. Tortajada. 2019. Water quality management: a globally a neglected issue. International of Water Resouces Development. Issue 6, Vol 35, Pages 913-916.

Braat, L.C. and R. de Groot. 2012. The ecosystem services agenda: bridging the worlds of natural science and economics, Conservation and Development, and Public and Private Policy. Journal of Ecosystem Services 1, 4-15. journal homepage: www.elsevier.com/locate/ecoser.

Brook, B.W. 2004. The carrying capacity of ecosystem. Centre for Tropical Wildlife Management, Charles Darwin University, Darwin, NT 0909, Australia.

Calatrava, J. and D.M. Granados. 2018. Water buyback to recover depleted aquifers in Southeast Spain. International of Water Resouces Development. Issue 6, Vol 35, Pages 977-998.

Cisberos, M.A.H., N.V.R. Sarmiento, C.A. Delrieux, M.C. Piccolo, and G.M.E. Perillo. 2016. Beach carrying capacity assessment through image processing tools for coastal management. Elsevier. Ocean and Coastal Management. Volume 130, pages 138-147. 
de Groot, R., 2012. Global estimates of the value of ecosystem and their services in monetary units. Journal of Ecosystem Services 1, 50-60.

Dinas Energi dan Sumber Daya Mineral Provinsi Sulawesi Tenggara. 2018. Data Potensi Air Tanah Kabupaten Buton Tengah. Kendari, Sulawesi Tenggara.

Direktorat Jenderal Planologi Kehutanan dan Tata Lingkungan Kementerian Lingkungan Hidup dan Kehutanan. 2017. Data Karakteristik Ekoregion Provinsi Sulawesi Tenggara. Balai Pemantapan Kawasan Hutan, Kendari. Sulawesi Tenggara.

Hall, A and M. Day. 2011. Ecotourism in in the state forest karst of Puerto Rico. Journal of Cave and Karst Studies, v. 76, no. 1, p. 30-41. DOI: $10.4311 / 2011$ SSO263.

Hanjra, M.A. and M.E. Qureshi. 2010. Global water crisis and future food security in an era of climate change. Food Policy. Volume 35, Issue 5, Pages 365-377.

Hein, L., K. Koppen, R. de Groot, and C. Van lerland. 2006. Spatial scales, stakeholders and the valuation of ecosystem services. Ecological Economics Journal. Volume 57, Issue 2, Page 209228.

Kavouzi, A. And E. Raeizi. 2015. Estimation of groundwater mean residence time in unconfined karst aquifers using recession curves. Journal of Cave and Karst Studies, v, 77, no. 2, p. 108-119.

DOI: 10.4311/2014ESO106

Kremen, C. 2005. Managing Ecosystem Services: What do We Need to Know About Ecology. Department of Ecology and Evolutionary Biology, Princeton University, Guyot Hall, Washington Rd, Princeton, NJ 08544, USA

La Baco S., L. Yunus, L. Indriyani, B. Mursidi dan Albasri. 2018. Kajian dan Pemetaan Sumber Air di Kabupaten Buton Tengah. Kerjasama Badan Perencanaan Pembangunan Daerah Kabupaten Buton Tengah dengan Lembaga Penelitian dan Pengabdian Kepada Masyarakat Universitas Halu Oleo. Labungkari, Buton Tengah.

Luker, E, and L.M. Harris. 2018. Developing new urban water supplies: investigating and motivations and barriers to groundwater use in Cape Town. International of Water Resouces Development. Issue 6, Vol 35, Pages 917-937.

Nam, J., W.K. Chang, and D. Kang. 2010. Carrying capacity of an uninhabited island of southwestern coast of korea. Elsevier. Ecological Modelling, Volume 221, Issue 17, Pages 2102-2107.

Nassimi, A and Z. Mohammadi. 2015. Comparison of the results of pumping and tracer Tests in a karst terrain. Journal of Cave and Karst Studies, v. 78, no. 2, p. 110-118, DOI: 10.4311/2015ES0119.

Pandeya, B., W. Buytaert, Z. Zulkafli, T. Karpouzoglou, F. Mau, and D.M. Hannah. 2016. A comparative analysis of ecosystem sercives valuation approaches for aplication at the local scale and in data scarce region. Journal of Ecosystem Services 22, 250-259. homepage:

www.elsevier.com/locate/ecoser

Peraturan Menteri Lingkungan Hidup nomor 17 Tahun 2009. Pedoman Penentuan Daya Dukung Lingkungan Hidup Dalam Penataan Ruang. Jakarta, Indonesia.

Qiuyun, J., F. Guoji, L. Mulian, W. Yuyun, and $X$. Jingxuan. 2011. Research on tourism water resources carrying capacity engineering in Hainan Province. 
System Engineering Procedia 1 (2011) 384-391. Elsevier.

Senoaji, G. 2009. Daya dukung lingkungan dan kesesuaian lahan dalam pengembangan Pulau Enggano Bengkulu. Jurnal Bumi Lestari Volume 9, No 2, Hal. 159166.

Shokri, M., J. Ashjari, and G. Karami. 2014. Surface and subsurface karstification of aquifers in arid regions: The Case Study of Cheshme-Ali Spring, Iran. Journal of Cave and Karst Studies, v. 78, no. 1, p. 25-35. DOI: $10.4311 / 2014 E S 0020$.

Smiley, S.L. 2018. Explaining and inprovements and continuing challenges in water access in dar es Salaam, Tanzania. International of Water Resouces Development. Issue 6, Vol 35, Pages 959-976.

Undang-undang Nomor 32 Tahun 2009. Perlindungan dan Pengelolaan Lingkungan Hidup. Lembaran Negara Republik Indonesia Tahun 2009 Nomor 140. Jakarta, Indonesia.
Vigna, B., I. M. D’Angeli, A. Florucci, and D.J. Waele. 2017. Hydrogeological flow in gypsum karst areas: some examples from northern Italy and main circulation model. International Journal of Speleology. 46 (2) 205-207, Tampa, FL-USA.

Yu, V.L.,Y.Z.Feng, and L. Wei. 2005. Theory and evaluation of urban ecosystem carrying capacity. State Key Joint Laboratory of Environmental Simulation and Pollution Control, School of Environment, Beijing Normal University, Beijing 100875, China.

Zhu, Y., S. Drake, H. Lu, and J. Xia. 2009. Analysis of temporal and spatial differences in ecoenvironmental carrying capacity related to water in the Haihe River Babsin, China. State Key Laboratory of Hydrology-Water Resources and Hydraulic Engineering, College of Water Resources and Environment Hohai Univesity Naijing, China. 